\title{
Ideological Leaning and Praxis of Housing Co- operatives in South Africa: Matters Arising
}

Jimoh Richard, (Federal University of Technology Minna, Nigeria)

Jasper van Wyk, (Nelson Mandela Metropolitan University, South Africa)

\begin{abstract}
Social movements came about as a result of dissatisfaction felt by society from the status quo. The grievances are presented through demonstrations, strikes, riots, occupation of land, boycott of business or by the development of social and economic alternatives such as self-help schemes or saving clubs. In South Africa, people join housing co-operatives because it takes a long time to wait for the Reconstruction Development Project (RDP) houses promised by the Government. The leaning of 5 housing co-operatives was examined within the context of ideology and praxis that are components of triad model. This was done through a multi-case study whereby the chairpersons of the housing co-operatives were interviewed using structured interview format. Findings from the study indicated that the housing co-operatives were not all open and voluntary; also, the housing co-operatives were not administered the same way. In all, efforts were put in by the housing co-operatives in engendering the ideology of co-operatives on one hand and the government on the other hand to provide the necessary subsidy so that the gap in the housing deficit could be bridged.
\end{abstract}

Keywords: Housing, Co-operatives, Ideology, Praxis, Principles, South Africa

\section{Housing Co-operatives in South Africa}

In 1996, the Gauteng Provincial Board enabled the approximately 2000 tenants of seven apartment buildings in Hillbrow, Joubert Park and Berea to become owners of the flats they were living in (SHF, 2000; Cull, 2001; Rust, 2001; Fish, 2003; Crofton, 2006 \& NDoH, 2009). This marked the beginning of housing co-operatives in Johannesburg's inner city and to a large extent South Africa, as there was no prior documented evidence of the use of cooperatives to access the institutional subsidy of government. The question is why has it taken this long for this approach to be used in housing delivery?

\begin{tabular}{|c|c|c|c|c|c|}
\hline TYPE OF PROPERTY & GAUTENG & $\begin{array}{c}\text { NORTH } \\
\text { WEST }\end{array}$ & $\begin{array}{l}\text { WESTERN } \\
\text { CAPE }\end{array}$ & $\begin{array}{l}\text { KWAZULU- } \\
\text { NATAL }\end{array}$ & $\begin{array}{c}\text { EASTERN } \\
\text { CAPE }\end{array}$ \\
\hline PHP \& INFORMAL & 1 & 1 & 0 & 9 & 11 \\
\hline HOSTEL UPGRADE & 0 & 0 & 2 & 0 & 0 \\
\hline GREENFIELD & 2 & 0 & 0 & 1 & 0 \\
\hline FLATS RENOVATION & 20 & 10 & 1 & 0 & 0 \\
\hline TOTAL & 23 & 11 & 3 & 10 & 11 \\
\hline TOTAL UNITS & \multicolumn{5}{|c|}{105,000} \\
\hline OWNERSHIP & \multicolumn{5}{|c|}{ 70\% BLACKS, 25\% COLOUREDS, 5\% INDIANS } \\
\hline DEMOGRAPHICS & \multicolumn{5}{|c|}{$50 \%$ WOMEN, $40 \%$ YOUTH \& 10\% DISABLED } \\
\hline $\begin{array}{l}\text { EMPLOYMENT } \\
\text { OPPORTUNITY }\end{array}$ & \multicolumn{5}{|c|}{ 1,715 PERMANENT EMPLOYEES } \\
\hline
\end{tabular}

Table 1 National Co-operative Housing Membership Statistics in Five Provinces

Source: Matsela, 2010; presentation on housing co-operatives to the National Housing Portfolio Committee Parliament, Cape Town. 
Table 1 above is an indication of the low number of housing co-operatives in South Africa. Four provinces, namely Mpumalanga, Northern Cape, Free State and Limpopo are not represented. Even those represented show low membership statistics. However, in the later part of the 1990s, with the slower rate in the delivery of housing by government, people started looking back at the rationale behind the communal approaches to addressing their housing needs.

\section{The Developmental Phases in Co-operative Housing}

The CCMH (Commission on Co-operative and Mutual Housing, 2009) stated that there are three stages or phases of evolution of housing co-operatives up to the present time:

- The first phase is characterised by grass roots bottom up initiatives by trade unionists or housing and community activists experimenting with the development of housing cooperatives as a means of meeting the housing needs of people who are not able to get a decent home that they can afford. In countries such as Germany, Austria, Sweden and Canada, as stated by CCMH (2009), that were the pioneers of the co-operative housing approach, this phase was characterised by not well defined legal and financial frameworks and limited professional and technical expertise.

- Phase two replicates, consolidates and adapts successful pioneering experiments, leading to the emergence of a recognisable co-operative housing subsector. Regional and national federations of co-operative and mutual housing start to form; support services able to facilitate the development of co-operative and mutual housing begin to develop and codes of conduct and best practice begin to emerge. CCMH (2009) emphasised that the success of this phase was attributable to two reasons:

oThe advocacy role of the national co-operative movements in countries such as Germany, Austria, Sweden, Norway and Canada. This was dependent on the belief exhibited by the various governments that the co-operative housing could help to solve the housing problem of the people; and

o The formation of savings and loan schemes established for members to save towards their co-operative membership shares.

- Phase three, according to CCMH (2009), is the period when co-operative housing has been the entrenchment in the psyche of the public; a situation where specific provision is made for co-operative and mutual housing within the national legislation and housing systems. The level of support received by the housing co-operatives from their various governments may be connected with the percentage of housing stock provided through the co-operative housing approach.

$\mathrm{CCMH}$ (2009) stated that the phases do not have a distinct division among them; a phase does not start and finish before the next one can begin. The development of the phases differs from one country to another but the common denominator is that housing cooperatives pass through the three phases for a sustainable co-operative housing subsector to be developed.

From the above characterisation, the South African housing co-operatives are at the first phase, where the rate of failure is at its highest. If efforts are not put in place to ensure that the housing co-operatives develop past that phase, it is not likely to move to the next phase. This phase requires a lot of sacrifices on the part of all the stakeholders. The developmental phases in co-operative housing has shown that without beneficial legislative and policy frameworks in place, the growth, development and sustainability of housing co-operatives will be near impossible.

Richard J and van Wyk J (2013) 'Ideological leaning and praxis of housing co-operatives in South Africa: Matters arising', Australasian Journal of Construction Economics and Building, 13 (2) 54-66 


\section{The Problems of Housing Co-operatives}

In spite of the benefits that could be derived from co-operative housing as a delivery option, housing co-operatives around the world are beset by problems ranging from inadequate legislative frameworks, lack of understanding of the public and government officials on cooperative housing to inadequate finance as established by Nubi, 2009; Eglin, 2008; Nnkya, 2001; Byaruhanga, 2001; Fruet, 2005; Fall, 2009; Mubvami \& Kamete, 2001; CMHN \& VNC, 2004; CMHC, 2003 and McClean \& Onyx, 2009. These problems are tabulated in Table 2:

\begin{tabular}{|l|l|}
\hline \multicolumn{1}{|c|}{ Developing countries } & \multicolumn{1}{|c|}{ Developed countries } \\
\hline $\begin{array}{l}\text { Lack of awareness by the officials of } \\
\text { government. }\end{array}$ & $\begin{array}{l}\text { Lack of information and knowledge on co- } \\
\text { operative housing. }\end{array}$ \\
\hline $\begin{array}{l}\text { Unfavourable legislation towards co- } \\
\text { operative housing. }\end{array}$ & Inappropriate regulation framework. \\
\hline $\begin{array}{l}\text { Interference by agency responsible for } \\
\text { housing delivery. }\end{array}$ & Lack of support structures. \\
\hline $\begin{array}{l}\text { Opposition to co-operative model. } \\
\text { Lack of support by all the spheres of } \\
\text { government. }\end{array}$ & Restrictive regulation. \\
\hline Lack of access to finance. & Lack of sustainable finance. \\
\hline $\begin{array}{l}\text { Weak internal control. } \\
\text { Non payment of fees by the members. }\end{array}$ & Inadequate management structure. \\
\hline $\begin{array}{l}\text { Lack of understanding by the members on } \\
\text { co-operatives. }\end{array}$ & $\begin{array}{l}\text { Inadequate education and participation by the } \\
\text { members. }\end{array}$ \\
\hline
\end{tabular}

Table 2 Problems Experienced by Housing Co-operatives in Developing and Developed Countries (Source: Authors own summary)

For the purpose of the summary in Table 2, the developing countries are Nigeria, South Africa, Tanzania, Uganda, Brazil, Senegal and Zimbabwe. Developed countries are United States, U.K, Canada and Australia.

The above tabulation brings a salient issue to the fore, irrespective of where the housing cooperatives are based, the challenges are the same.

\section{Theoretical Framework}

From the previous literature review, the problems that housing co-operatives experienced in different countries around the world were identified and presented in Table 2. The problems can be grouped into two categories: The first has to do with the mobilisation of resources such as land and finance and secondly, organising these resources based on the principles of co-operatives, which form the mainstay of any housing co-operative. These principles distinguish housing co-operatives from other co-operative-like initiatives; hence the need to locate the study within a theory or model for proper understanding of the research was imperative. The study was anchored on the Develtere model, called the "triad" model shown in Figure 1 below.

It was used to study social movements in co-operatives, since housing co-operatives is a microcosm of a co-operative movement; hence the model can be used. Gerard and Martens (cited by Develtere, n.d.) distinguished three components or forces in all social and cooperative movements. The ideology of the movements present the images of a desirable society based on specified values and the ways to achieve them. There is also the praxis or the action that is responsible for the mobilization and participation of the membership base. 
To realize their objectives, as stated by Gerard and Martens (cited by Develtere, n.d.), they also develop at least a minimal organisational structure.

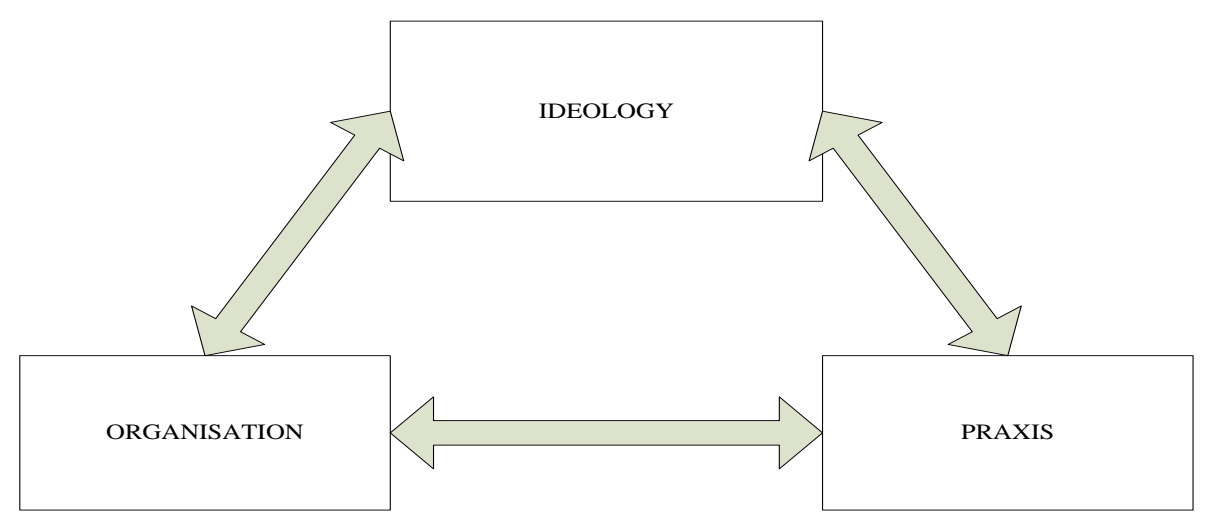

Figure 1: The three components of co-operative movements in developing countries adapted from Develtere (n.d.), page 39.

Develtere (n.d.) established that there is a continuous interaction among the components (the ideology, the praxis and the organisation). Over the years, due to the resources deployed by the members of co-operatives through their participation in co-operative activities, the ideology is created and recreated. This ideology determines who can be members and the resources expected from the members. Based on the ideology and the praxis, according to Develtere (n.d.), the structure of the organisation (in this case the cooperative) is defined. The interaction of these components creates the identity of a social movement (Develtere, n.d.).

Social movements came about as a result of dissatisfaction felt by society from the status quo, as emphasized by Develtere (n.d.). They present their grievances through demonstrations, strikes, riots, occupation of land, boycott of business or by the development of social and economic alternatives such as self-help schemes or saving clubs. In South Africa, people join housing co-operatives because it takes a long time to wait for the Reconstruction Development Project (RDP) houses promised by the Government. They also want to have control of the outcome of their houses when completed. In other climes where there are no subsidies, as is being provided in South Africa, people form housing cooperatives where ordinarily they would have been incapacitated as individuals to get control of their destiny (Willie-Nwobu cited by Olusanya, 2000).

As stated at the outset, housing co-operative is a microcosm of the co-operative movement. Since the study was based on an in-depth understanding of housing co-operatives in South Africa, it has to do with the interplay of the principle of co-operatives (ideology); the praxis (the resources employed by both the members and external bodies such as donor agencies and government) and the way the organisation is structured. In order words, it investigated how the housing co-operatives adhered to these principles, the way resources were employed by both the government and the housing co-operatives members and finally, the way the members structured their various housing co-operatives. Develtere's "triad" model was suitable for the study. Only 2 (two) of the components of the model (ideology and praxis) were reported in this paper which covered open and voluntary membership; education, training and information; democracy; autonomy and finance. 


\section{Research Methodology}

A multi-case study method was used. Gummesson (2007) defined a case study research as one where cases from real life are used as empirical data for research, especially when knowledge of an area is sparse or missing. Yin (2009) stated that a case study is used when a "how" or "why" question is being asked about a contemporary set of events over which the investigator has little or no control, and the boundaries between phenomenon and context are not clearly evident. For the purpose of this study, structured interviews were used with both closed and open ended questions asked from the interviewees.

In determining the number of housing co-operatives to be interviewed, purposive sampling was used. This sampling technique is a non-probability sampling procedure which is usually used in qualitative research that has to do with selecting the people to be interviewed based on the interviewer's knowledge on the appropriateness and typicality of the sample selected (David \& Sutton, 2004; Cohen et al, 2005; Teddlie \& Yu, 2007). Eisenhardt (cited by Meyer, 2001) stated that the logic of the sampling is different from statistical sampling because the idea is to select cases that are replicable or be able to further the emergent theory. Yin (2009) suggested that 2 or 3 cases could be selected for literal replication whereas 4 to 6 cases can be used to study theoretical replication (predicting contrasting results).

Initially, 6 cases were selected from the housing co-operatives in Johannesburg for this study based on the following parameters:

- Due to the large concentration of housing co-operatives in Johannesburg; there were twenty-nine housing co-operatives identified based on the list from the Registrar of Cooperatives Office;

- The cosmopolitan nature of the city that makes the poor, with limited or inadequate housing, continue to migrate there in search of opportunities. It is the belief of the National Government that co-operative housing could be explored to solve the housing problem of this group of people (NDoH, 2009); and

- The selection of housing co-operatives that have been in business of providing housing for their members for more than 3 years. It was the belief of the authors that this set of housing co-operatives will provide more insight than those that have just started out.

However, only 5 housing co-operative chairpersons were interviewed, due to the fact that one of the housing co-operatives identified requested an interpreter. The authors decided not to interview this chairperson because of fear of misinterpretation or inadequate interpretation from the interpreter. The first interview was conducted on 26 May 2011 and lasted for 30 minutes. It was recorded and notes were also taken. The permission of the interviewee was sought before recording the interview.

The second interview took place on 29 May 2011. It was difficult to interview the other 4 chairpersons individually because the convenient time for them was before their provincial meeting. As a result of this, it was necessary to change the format of interviewing adopted in the first interview to group interviewing. In this approach, the authors asked questions based on the research guide, while the chairpersons answered them in the interview guide given to each of them based on the peculiarity of their respective housing co-operatives. There was no need to sound record this session, since each individual housing co-operative answered in writing and enough time was usually given for all those present to complete a particular question before moving to the next one. This session lasted for 2 hours and 25 minutes. 


\section{Results and Discussions}

\section{Profiles of the Housing Co-operatives Interviewed}

\begin{tabular}{|l|c|c|c|c|c|}
\hline \multicolumn{1}{|c|}{ Profile } & $\begin{array}{c}\text { Co-op } \\
\text { A }\end{array}$ & $\begin{array}{c}\text { Co-op } \\
\text { B }\end{array}$ & $\begin{array}{c}\text { Co-op } \\
\text { C }\end{array}$ & $\begin{array}{c}\text { Co-op } \\
\text { D }\end{array}$ & $\begin{array}{c}\text { Co-op } \\
\text { E }\end{array}$ \\
\hline Year established & 2000 & 1999 & 1999 & 1999 & 1999 \\
\hline $\begin{array}{l}\text { Year registered at Companies \& Intellectual } \\
\text { Property Registration Office (CIPRO) }\end{array}$ & 2001 & 2001 & 1999 & 2000 & 2001 \\
\hline Number of members & 120 & 351 & 55 & 84 & 28 \\
\hline Number of houses & 120 & 351 & 55 & 84 & 28 \\
\hline
\end{tabular}

Table 3 Profiles of the Five (5) Housing Co-operatives Interviewed

The above table shows the years the housing co-operatives were established and when they were registered at CIPRO. As stated earlier, the year of establishment was a condition in the selection of the housing co-operatives to be interviewed. All the housing co-operatives have been in 'business' for more than twelve years which is an indication that the information supplied can be relied upon.

\section{Open and Voluntary Membership}

The first principle of all the co-operatives irrespective of $t$ type is for the membership to be open and voluntary. The extent to which this principle was pursued by the co-operatives varied based on underlying parameters establishing such co-operatives. In South Africa the development of housing co-operatives hinged on the subsidy provision of the National Government from the beginning hence the open and voluntary nature of the membership was restricted. To be eligible for the subsidy, prospective beneficiaries must be in a household with a joint income of between $\$ 143-\$ 700$. In this respect none of the housing cooperatives could be said to be open and voluntary to new members.

\section{Education, Training and Information}

It was discovered that out of the four organisations listed [the Small Enterprises Development Agency (SEDA), Social Housing Foundation (SHF), South Africa Housing Cooperatives Association (SAHCA) and Non Governmental Organisations (NGOs)], the housing co-operatives only availed themselves of the training conducted by SAHCA. The training provided by SAHCA according to the interviewees ranged from adequate to fairly adequate; hence, they all canvassed for improvements to be made. The chairperson of housing co-operative A was aware of the existence of the SHF, but did not know the procedures to follow in order to benefit from its workshops and training opportunities. Education and information are important, but were lacking in this instance; probably not due to the fault of the chairpersons but as a result of limited promotion of SHF activities that would have informed housing co-operatives of how to approach the SHF for training.

SEDA, according to DTI (2010), was an agency of the Department of Trade and Industry which among other services provided social and skills enhancement for co-operative members and to support and promote co-operatives. The support provided was usually in the form of training on how business plans were prepared and how to run the co-operative. The SHF (the responsibilities has now been taken over by Social Housing Regulatory Authority [SHRA]) was also a government agency accountable to the Department of Human Settlements and was expected to develop a sustainable social housing sector for South Africa. This goal was approached by implementing rental strategy and providing training and workshops within the confines of the social housing sector (UN-Habitat, 2008 \& SHF, 2009). 
It was stated that the housing co-operatives offered education and training to both the members of the housing co-operatives and the employees. In addition to these, public enlightenment was also provided. A classic example was given by housing co-operative $B$ to the effect that across the road, there was rental housing that charged more than the housing co-operative was charging on a monthly basis and that no better enlightenment could be found. Corroborating the responses of the interviewees, during the second interview, someone from Canada was introduced by the President of SAHCA to the members present. The national body facilitated the arrangement in order for the housing co-operatives to be taught the development in co-operatives in general and housing co-operatives in particular.

\section{Democracy}

In housing co-operative $A$, the Board members were usually elected by the members and were expected to serve for three (3) years. The committee members were also expected to serve for three (3) years and were selected by the Board members. This arrangement for selecting committee members is not in line with democratic tenets and is capable of being abused by the Board of Directors, especially when the Board of Directors' associates are selected to be members of the committee. One good thing here was that the housing cooperative had only one committee: the finance committee; hence the extent of abuse of power was reduced. The positive aspect of this selection of committee members was that the chairperson stated that the finance committee was often effective in discharging its functions.

In taking decisions, the following were usually adhered to by the housing co-operative:

- Major decisions were taken at the general meetings.

- Important and minor decisions were taken by the Board members.

In housing co-operative $B$, the situation was somehow different. The Board members were usually elected for more than four (4) years and due to the re-organisation going on in the housing co-operative, there was no committee in place. Electing Board members to run for more than four years could lead to vices such as lack of accountability, favouritism, corruption, apathy and perpetuation of self interest (CCMH, 2009). In taking decisions, the general secretary indicated that major and important decisions were normally taken by the Board members while minor decisions were left to be decided at the general meetings. This type of arrangement will only further perpetuate some of the vices earlier mentioned. Though running housing co-operatives by general meetings according to $\mathrm{CCMH}$ (2009) could lead to a situation where the housing co-operative may become difficult to administer it would have been more appropriate to have major and important decisions vested in the general meetings to ensure checks and balances. However, annual general meetings have not been held for sometime due to the re-organisation going on in the housing co-operative.

In housing co-operative $\mathrm{C}$, the situation was that both the Board members and committee members were elected and are expected to run for four (4) years and one (1) year respectively. There were maintenance and social committees which were mostly effective in the discharge of their responsibilities. This may be connected with the limited time allowable for the committees; the idea of positively impacting the housing co-operative cannot be overemphasised. Important and minor decisions were usually taken by the Board members while major decisions were taken at the general meetings. Annual general meetings were held annually. In housing co-operative $\mathrm{D}$, both the Board members and committee members were elected for a period of three (3) years and there were maintenance, finance and social committees in place. Major decisions were taken at the general meetings while Board members take important and minor decisions. Annual meetings took place every year.

Richard J and van Wyk J (2013) 'Ideological leaning and praxis of housing co-operatives in South Africa: Matters arising', Australasian Journal of Construction Economics and Building, 13 (2) 54-66 
Lastly, in housing co-operative E, Board members and committee members were elected for a period of four (4) years and one (1) year respectively and there were maintenance, finance and social committees in place. Major decisions were usually taken at the general meetings while Board members took important and minor decisions.

Of note is that in all the housing co-operatives, women have been very active in their participation in the activities of the co-operatives. For housing co-operatives to be sustainable, the interviewee stressed that women should be given equal opportunities and should be supported to achieve this.

The strength of any housing co-operative is hinged on the members' participation and as such the housing co-operatives embarked on the following measures to ensure adequate members participation in addition to the annual general meetings:

- New members were informed of the need to participate actively in the co-operative activities. This measure was sometimes effective as observed by the chairperson.

- Providing training for all the committee members. This measure was important and has been found to be very effective.

- Regular house to house visits was also an effective measure usually adopted by the housing co-operative in ensuring members' participation.

- In addition to the above measures, housing co-operatives $D$ and $E$ imposed fines when members fall due in their participation.

\section{Autonomy}

One of the principles of co-operatives is that they should be autonomous; hence they should not be subjected to external control from bodies such as government and donor agencies. Housing co-operatives $A$ and $B$ claimed that there has never been a time when any agency of the government, SHF, SAHCA and the Board of Directors tried to impose their will on the housing co-operatives. However, when looked at from the perspective of monitoring and evaluation, this is not a positive development because it implies that the housing cooperative was left to either 'swim or sink'. A modicum of control was expected especially when the subsidy of government was involved, as it was in these cases. However, the story was different in housing co-operatives $C, D$ and $E$ that have been subjected to some form of control.

\section{Finance}

The chairpersons were asked about the various sources of finance available to the housing co-operatives and the level of adequacy. It was discovered that the housing co-operative $A$ had used members' contribution, government institutional housing subsidy and a loan from the National Housing Finance Corporation (NHFC) to finance the day to day activities of the housing co-operative. The NHFC, according to UN-Habitat (2008), was an agency of the Human Settlements Department, whose objective among others was the development and appropriate funding of institutions such as housing co-operatives, offering a variety of tenure arrangements for residential purposes in the areas of the housing market that were not well covered. As to the adequacy, members' contributions and the government institutional subsidy were very adequate while the loan from NHFC was adequate.

However, the other housing co-operatives (B, C, D and E) had only used members' contribution and government institutional housing subsidy. As to their adequacy, they claimed that only the subsidy was adequate except housing co-operative $E$ where both the subsidy and the members' contribution were adequate. None of the housing co-operatives was registered as a Social Housing Institution (SHI) in order to be able to benefit from 
government grants apart from the subsidy. Efforts of policy makers were not encouraging in creating sustainable co-operative housing. This statement was borne out of the statement that appeared on page 9 of the 2005 Social Housing Policy and page 18 of the 2009 Social Housing Policy as shown below:

\begin{abstract}
"Primary and secondary housing co-operatives registered under the Co-operatives Act of 1981, and accessing funding through this programme will be considered together with the social housing institutions and will have to be accredited as social housing institutions. Separate guidelines, however, will be drafted to accommodate the specific nature, operations and regulatory requirements of the housing co-operatives".
\end{abstract}

Four years after the first social housing policy was published, separate guidelines for housing co-operatives have not yet been drafted. Hence, it will become difficult for the housing co-operatives to access the social housing grant. Interestingly, the Co-operative Act of 1981 does not distinguish housing co-operatives from agricultural based co-operatives, which were predominant at that time; it was the Co-operatives Act 14 of 2005 that recognised other specialised co-operatives such as housing co-operatives. This further showed that there is a minimal understanding by the agency responsible for the formulation of housing policies and legislation vis-à-vis co-operatives policies and legislation. This limited understanding may be connected to the low level of growth and development experienced so far in the co-operative housing subsector. Apart from this, it was going to be difficult for housing co-operatives to benefit from the current grants, except if some aspects of the Social Housing Act 16 of 2008 were changed. This issue came up during the presentation of the Social Housing Act Regulations by the SHRA to the Portfolio Committee on Human Settlements on $7^{\text {th }}$ September 2011. The Committee remarked that no funding framework existed for housing co-operatives at the national level. This can be validated from page 9 of the 2005 Social Housing Policy and page 18 of the 2009 Social Housing Policy highlighted above.

The institutional subsidy that formed the main subsidy that housing co-operatives use, was not exclusively for housing co-operatives but also for other housing institutions such as rental, share block and instalment sale. The main policy intent of the subsidy was to provide capital for the provision and maintenance of affordable rental housing (NDoH, 2009a). In essence, it amounted to the survival of the fittest in getting the subsidy.

In spending the funds of housing co-operative $A$, it was the responsibility of the members and the Board members to decide on how the money of the co-operative was spent. This was a good method as it checked the unilateral spending by either the chairperson or the person in charge of finance. Also, this housing co-operative as a matter of statutory regulation ensured that its accounts were audited as enshrined in the 2005 co-operatives Act 14 in Section 47 Subsections 1d, although a co-operative may apply for exemption to the Registrar of Co-operatives if for reasons of finance the co-operative could not meet the requirements. Housing co-operatives $B$ and $C$ accounts were (as at the time of the interview) administered in a trust account. This may be indication of a problem in the housing cooperatives. In co-operatives $D$ and $E$, the chairperson and the person in-charge of finance authorized the spending of the co-operative's funds.

To ensure that members pay their fees, the following measures were put in place by all the housing co-operatives:

- Initially, electricity to defaulters were disconnected but this policy resulted in the defaulters seeking redress in court. The policy was later terminated as it was not in the statutes of the housing co-operative;

- Presentation of letter of demand to the defaulter and

- Evicting defaulters. Over the years, members have been evicted.

Richard J and van Wyk J (2013) 'Ideological leaning and praxis of housing co-operatives in South Africa: Matters arising', Australasian Journal of Construction Economics and Building, 13 (2) 54-66 
The eviction of members of the housing co-operatives was something that should have been looked into as it was not a positive development. In a study of the co-operative housing subsector conducted by the Community and Neighbourhood Services Department, City of Toronto (2004), the following eviction prevention strategies were suggested:

- Eviction should be the last resort;

- Provision of late notices;

- A progressive approach to arrears management and conflict resolution;

- Repayment schedules;

- Provision of clear information on the eviction process, options and rights; and

- Allowance of time and opportunity to explain and resolve problems such as arrears and to contest eviction.

\section{Matters Arising}

All co-operatives, according to Johnston (1999), are in several ways created with ideology that is predetermined. In essence, there is a mission that each co-operative wants to achieve that is encapsulated in the co-operative principles. The implementation of these principles as stated by Johnston (1999) differs from one country to the other and also from one cooperative to the other. Hence, the essence of the principles is to provide a framework for cooperatives to carry out their businesses. Co-operative business is just a means to an end, a method of doing business which results in advantages to the society not otherwise possible in a capitalist system.

In a collection of 21 cases of housing co-operatives from 12 countries reported in Munkner (2009), none of the housing co-operatives was able to apply all the principles of cooperatives but became distinctive by one form of the principle or the other. Munkner (2009) concluded that what is important in any housing co-operative is the promotion of the interest of the members and that the existence of housing co-operatives hinges on this. Of note is that all over the world, there are different models of housing co-operatives available because of their flexibility to suit the environment in which they operate. In the words of Munkner and Trodin (1999), there is no single model for the development of self-help organisations, of which housing co-operatives is one that can be transferred from one country or region to another. Munkner and Trodin (ibid) are of the view that experience has shown that housing co-operatives differ from one community to another. For housing co-operatives to be successful, they have to be structured in line with the local needs of the members. This is not to say that best practice cannot be copied but with adaptations to suit the local needs of the members. Irrespective of the model chosen, the principles of co-operatives have to be embedded because without that, there is no housing co-operative.

The praxis may be broken down into internal and external actions. The internal praxis consists of members participating in the decision making in areas such as electing/selecting members to Boards of Directors, attending meetings or paying all levies. While external praxis refers to the relationship between housing co-operatives and other bodies such as government and donor agencies in terms of resources provision. Where the State provides the bulk of the finances through institutional subsidies the issue of autonomy may in the long run become challenging as government may control operational decisions hitherto taken by the Board of Directors. This will make the housing co-operatives unable to function as member owned and democratically controlled organisations. This scenario was seen in the membership structures of the housing co-operatives studied, as prospective members have to be in an income bracket to qualify for the subsidy. To curb this dependence on the government, members have to demonstrate commitment to internal practices. 


\section{Conclusions}

Five housing co-operatives based in Johannesburg, South Africa have been examined using the triad model for their ideology and practises. The housing co-operatives examined were not open since membership depended on being a citizen within certain income bracket due to the institutional subsidy from the government that is involved. The test showed a mixed result on the matter of democracy as reflected in the ways the housing co-operatives chose their executives and committee members (internal praxis). The tests showed the same result for finance. In all, efforts were put in by the housing co-operatives in engendering the ideology of co-operatives on one hand and the government on the other hand to gain the necessary subsidy (external praxis) designed to reduce the housing deficit.

\section{References}

Byaruhanga, E.M. (2001) Shelter Co-operatives in Uganda: Contributions of the Cooperative Sector to Shelter Development. Available from: www.UN-Habitat.org/publications/ (Accessed 25 January 2010)

$\mathrm{CCMH}$ (2009) Bringing democracy home, Edited by Bliss, N. Available from: www.cch.coop/.../bdh-commission-report.pdf (Accessed 17 May 2010)

CMHC (2003) Crisis situations in co-operatives: Better interventions hinge on a better understanding. Research Highlight: Socio-economic Series 03-003, April

CMHN \& VNC (2004) Affordable housing co-operatives conditions \& prospects in Chicago, Available from: www.uic.wisc.edu/cuppa/voorheestr/ (Accessed 26 April 2010)

Cohen, L., Manion, L. \& Morrison, K. (2005) Research methods in education. $5^{\text {th }}$ edition, Taylor \& Francis e-library, London

Community \& Neighbourhood Services Department (2004) Analysis of evictions in the City of Toronto: Co-operative housing sector. Available from: www.toronto.ca/housing/... (Accessed 27 May 2011)

Crofton, O. (2006) Housing co-operatives in South Africa: Experiences and lessons. Housing in Southern Africa, February

Cull, T. (2001) The seven buildings project: Is co-operative housing the answer to South Africa's housing crisis? Africa Insight, 31 (1), 43-49

David, M. \& Sutton, C.D. (2004) Social research: The basics. $1^{\text {st }}$ edition, Sage Publications Inc., California

Develtere, P. (n.d.) Co-operative and Development: Towards a Social Movement Perspective. Available from: www.usaskstudies.coop/pdf-files/ (Accessed 10 February 2011)

Department of Trade \& Industry (2005) Co-operatives Act (No 14 of 2005). Available from: www.dti.gov.za/DownloadsFileAction/ (Accessed 23 January 2010)

Department of Trade \& Industry (2010) The DTI co-operatives handbook 2010. Available from: www.dti.gov.za/DownloadsFileAction/ (Accessed 19 September 2011)

Eglin, R. (2008) Housing co-operatives: Lessons from Afesis-Corplan's co-operative housing experience. Available from: www.afesis.org.za/publications (Accessed 24 March 2010)

Fall, A.S. (2008) 'The Senegalese co-operative movement: Embedded in the social economy', In Co-operating out of poverty: The renaissance of the African co-operative movement. Edited by Develtere, P, Pollet, I \& Wanyama, F. Available from: www.ilo.org/coop out of poverty/ (Accessed 11 March 2009)

Fish, M. (2003) 'Social housing', In Housing policy and practice in post-apartheid South Africa. Edited by Khan, F \& Thring, P. Heinemann publishers limited, South Africa, 409-410 
Fruet, G.M. (2005) The low-income housing co-operatives in Porto Alegre, Brazil: A state/community partnership, Habitat International, 29, 303-324

Gummesson, E. (2007) 'Case study Research', In The Principles of Knowledge Creation: Research Methods in the Social Sciences. Edited by Gustavsson, B. Edward Elgar, UK, 87

Johnston, H. (1999) Social movement identity: an application of theory to the co-operative housing movement in Toronto. Available from www.collectionscanada.gc.ca/.../MQ46756.pdf (Accessed 10 February 2011)

Matsela, Z. (2010) Presentation on housing co-operatives by SAHCA to National Housing Portfolio Committee Parliament, Cape Town, 24 February

McClean, S. \& Onyx, J. (2009) Institutions \& social change: Implementing co-operative housing \& eventually sustainable development at Christie Walk, Cosmopolitan Civil Societies Journal, 1 (3), 109-131

Meyer, C.B. (2001) A case in case study methodology, Field Methods, 13 (4), 329-352

Mubvami, T. \& Kamete, A. (2001) Shelter Co-operatives in Zimbabwe: Contributions of the Co-operative Sector to Shelter Development. Available from: www.UNHabitat.org/publications/ (Accessed 25 January 2010)

Munkner, H.H. (Editor) (2009) Application of Co-operative Principle: 21 cases of housing cooperatives from 21 countries, Marburg Consult, Germany

Munkner, H.H. \& Trodin, R. (1999) Organised self-help to solve housing problems: A manual for organisers and local leaders of housing co-operatives among the urban poor, Marburg Consult, Germany

National Department of Housing (2005) Social Housing Policy for South Africa: Towards an enabling environment for social housing development. Available from: www.housing.gov.za/ (Accessed 3 February 2010)

National Department of Housing (2009) The National Housing Code, Part 3: Social Housing Policy. Available from: www.housing.gov.za/ (Accessed 6 May 2010)

National Department of Housing (2009a) The National Housing Code, Part 3: Institutional Subsidies. Available from: www.housing.gov.za/ (Accessed 6 May 2010)

Nnkya, T. (2001) Shelter Co-operatives in Tanzania: Contributions of the Co-operative Sector to Shelter Development. Available from: www.UN-Habitat.org/publications/ (Accessed 25 January 2010)

Nubi, T.O. (2009) Housing co-operatives as tools for housing affordability and availability, Housing Today, 1 (11), 14-25

Olusanya, O. (2000) Capacity Building in Housing Delivery: Strategy and Tactics for a Developing Economy. Paper presented at the $4^{\text {th }}$ International Conference on Housing, Abuja, Nigeria

Rust, K. (2001) Update on the status of Housing Co-operatives in South Africa; Draft report prepared for the Social Housing Foundation (SHF), October

SHF (2000) Guidelines for social housing design, SHF, Johannesburg

SHF (2009) The Social Housing Foundation annual report for 2008/2009. Available from: www.pmg.org.za/ (Accessed 22 March 2011).

South African Portfolio Committee on Human Settlements (2011) Social Housing Act regulations: Department of Human Settlements \& Social Housing Regulatory Authority Briefing, Parliamentary Monitoring Group, Cape Town

Teddlie, C. \& Yu, F. (2007) Mixed methods sampling: A typology with examples. Journal of Mixed Methods Research, 1 (1), 77-100 
UN-Habitat (2008) Housing Finance System in South Africa: The Human Settlements Finance Systems Series. Available from: www.unhabitat.org/publications/ (Accessed 25 January 2010)

Yin, R.K. (2009) Case Study Research: Design \& Methods, $4^{\text {th }}$ edition, Sage Publications, California 